\section{Agencies urge end to global trade restrictions on essential medicines}

Gavin Yamey BMJ

Intellectual property rights that protect drug patents, enforced by the World Trade Organisation, are preventing access of essential medicines to the developing world, warned an international coalition of health and legal professionals at a conference in Amsterdam last week.

Groups including the medical relief organisation Médecins Sans Frontières are calling on the World Trade Organisation to strengthen its provisions to help developing countries in bypassing patent law.

Patent protection of drugs can prevent poor countries from producing cheaper local versions, speakers warned delegates. In Thailand, for example, Pfizer used to be the sole supplier of fluconazole, used in treating cryptococcal meningitis, an opportunistic infection affecting 1 in 5 of the country's patients with AIDS. The company charged a daily price of $£ 8.75$
(\$14), making the drug largely unaffordable. The market exclusivity on the drug expired in 1998 , leading to its local production at $5 \%$ of the 1998 price (Lancet 1999;354:1893-5).

The conference examined the impact of the TRIPS (Trade Related Aspects of Intellectual Property Rights) agreements on access to medicines. Member states of the World Trade Organisation must abide by these multilateral agreements in trade negotiations. The agreements cover patent law and set minimum standards, such as 20 year patent protection for pharmaceuticals.

Representatives of Médecins Sans Frontières argued that there are two major provisions within the TRIPS agreements that could be used by the developing world to obtain cheaper essential drugs. Firstly, TRIPS allows for compulsory licensing, the right for local companies to produce patented medicines in exchange for a royalty payment to the patent holder. Secondly, it allows parallel imports, the legal right to import patented drugs sold more cheaply elsewhere.

Some wealthy countries, however, have attempted to prohibit poor countries from adopting these legal measures, as documented by the Consumer Project on Technology on its website (www.cptech.org). One example occurred when the United States unsuccessfully exerted trade pressure on the South African government to prevent its use of compulsory licensing and parallel imports. The Dutch minister for development, Eveline Herfkens, said: "We cannot accept the kind of bilateral dealings in which one country puts pressure on another. What the Netherlands wants is an open, transparent, multilateral system."

Director general of the World Health Organisation, Dr Gro Harlem Brundtland, said: "Recourse to compulsory licensing is a legitimate measure consistent with the TRIPS agreement."

\begin{tabular}{|c|c|}
\hline \multicolumn{2}{|c|}{$\begin{array}{l}\text { Candidate drugs for compulsory licensing-suggested by } \\
\text { Médecins Sans Frontières }\end{array}$} \\
\hline Generic drug & Public health use \\
\hline Azithromycin & Trachoma \\
\hline Ceftriaxone & Bacterial meningitis \\
\hline Ciprofloxacin & Shigella (Sd1) dysentery \\
\hline Didanosine (ddI) & HIV infection \\
\hline Fluconazole & Opportunistic infections \\
\hline Indinavir & HIV infection \\
\hline Lamivudine & HIV infection, hepatitis B \\
\hline Nevirapine & HIV infection \\
\hline Ofloxacin & Multidrug resistant tuberculosis \\
\hline Zidovudine & HIV infection \\
\hline
\end{tabular}

\section{No redress for failed sterilisations}

Clare Dyer legal correspondent, BMJ

The House of Lords, the United Kingdom's highest court, ruled last week that parents who produce a healthy child after a failed sterilisation or vasectomy have no right to claim compensation for the child's upbringing.

The decision, in a Scottish case, amazed English lawyers because it overturned an English Court of Appeal judgment in 1985 that led to scores of awards and settlements, with damages in some cases of more than $£ 100000$ (\$160000). The ruling now bars such damages throughout the United Kingdom, although small sums may still be awarded.

The law lords' ruling came on the same day as the High Court in Birmingham awarded record damages of $£ 1.3 \mathrm{~m}$ to a mother who gave birth to a severely handicapped son seven months after a negligently performed sterilisation. Shropshire Health Authority was ordered to pay the compensation to Gail Taylor, a former nurse who gave up work to look after her fifth child, John, now aged $10 . \mathrm{He}$ is autistic, epileptic, and asthmatic.

The judgment, against Shropshire Health Authority, may now be appealed because in the Scottish case the law lords left open the question of whether parents may be entitled to the cost of bringing up a handicapped child.

They allowed Tayside health board's appeal from a decision of the inner house of the Court of Session that George McFarlane and his wife, Laura, could recover the $£ 100000$ cost of bringing up their fifth child, Catherine, after the surgeon failed to warn of the risks of spontaneous recanalisation. Lord Steyn noted that counsel for the health board had conceded that the position might be different if the child had been born seriously disabled. $\mathrm{He}$ added: "There may be force in this concession, but it does not arise in the present appeal and it ought to wait decision where the focus is on such cases."

\title{
Israel health minister bans AIDS campaign promoting condoms
}

Judy Siegel-Itzkovich Jerusalem

Israel's health minister, ultraOrthodox rabbi Shlomo Benizri, has decided that the streets of Jerusalem-and elsewhere in Israel-would be "desecrated" by the sight of rolled up condoms on publicity posters for World AIDS Day. So he has ordered officials to destroy posters and pamphlets with the "embarrassing" objects and replace them with others that do not show condoms.

Minister Benizri's actions caused some surprise and disappointment among health professionals because when he came into office last summer (after three years as a deputy health minister) he declared his intention of giving high priority to disease prevention and health promotion. Israel has a relatively low rate of HIV infection, but the Israel AIDS Task Force-a voluntary organisation-claims that two or three residents out of a population of six million are newly infected each day.

Condoms are disapproved of as a form of birth control by Jewish law because their use constitutes wasteful "spilling of seed," as mentioned in the Bible. However, many rabbis have ruled that if a married man is found to have AIDS or to be an HIV carrier, if he does not agree to divorce his wife to save her from infection, he should use condoms during intercourse with her.

"I don't have the adequate words to express my disgust," declared Professor Zvi Bentwich, head of the AIDS clinic at Kaplan Hospital, Rehovot. "Apparently, his [Minister Benizri's] religious urges have overcome his senses. The endangerment of life must supersede the notion of modesty [about sexual matters]." 